\title{
Perspektif Lokalitas Bahan Pangan Alternatif bagi Masyarakat: Studi Eksperimental Pemberian Cucur Beras Merah terhadap Penderita Diabetes Melitus Tipe 2
}

Teguh Fathurrahman', Imanuddin ${ }^{2}$, Lena Atoy ${ }^{3}$, Astri Jelina ${ }^{4}$

1,2,3,4Poltekes Kemenkes Kendari, Sulawesi Tenggara, Indonesia Email: teguhkemenkes001@gmail.com

\section{Article Info \\ Article History \\ Received: 2021-11-20 \\ Revised: 2021-12-15}

Published: 2022-01-03

Keywords:

Diabetes Mellitus;

Red Rice;

Blood Glucose Level

\begin{abstract}
This type of research is an experimental study with a pre and post control design research design.In this research, we will look at the effectiveness of giving red rice flour cucur in reducing blood glucose levels of patients with diabetes mellitus in the working area of Kulisusu Public Health Center enter in North Buton district. The population of this research are 113 outpatient cases in Kulisusu Public Health Center work area. While the samples of this research while 30 . The analysis used in this research consisted of univariate analysis and bivariate analysis using the $\mathrm{T}$ Test statistic test, The results of the analysis using the T Paired Test statistic obtained $t$ count value 22,027>t table 2,045 which shows the effect of giving red rice flour cucur on fasting blood glucose levels of Diabetes Mellitustype 2 patients in the working area of Kulisusu Public Health Center, North Buton Regency.The provision of red rice cucur can reduce the rate of blood glucose levels by $42,4 \%$ in the treatment group which is seen in the difference of the average difference in fasting blood glucose levels and blood glucose 2 hours PP, There is an effect of giving red rice cucur on blood glucose levels of patients with diabetes mellitustype 2 in the working area of the Kulisusu Public Health Center in North Buton Regency based from the statistical analysis of the $t$ value of 22,027>t table of 2,045, which the product is able to suppress the rate of blood glucose levels 2 hours PP by $42.4 \%$ in the treatment group. Red rice cucur products are also favored by panelists who are sufferers of Diabetes MellitusType 2 in the working area of the Kulisusu Public Health Center in North Buton Regency after looking at several aspects of assessment such as color, aroma, taste and texture.
\end{abstract}

\begin{tabular}{l}
\hline Artikel Info \\
\hline Sejarah Artikel \\
Diterima: 2021-11-20 \\
Direvisi: 2021-12-15 \\
Dipublikasi: 2022-01-03
\end{tabular}

Kata kunci: Diabetes Mellitus; Beras Merah; Kadar Glukosa Darah.

\begin{abstract}
Abstrak
Jenis penelitian ini adalah penelitian eksperimental dengan desain penelitian pre and post control desain. Pada penelitian ini akan melihat efektifitas pemberian kue cucur tepung beras merah dalam menurunkan kadar glukosa darah penderita Diabetes Melitus di wilayah kerja puskesmas Kulisusu kabupaten buton utara. Populasi dalam penelitian ini sebanyak 113 pasien rawat jalan di wilayah kerja Puskesmas Kulisusu. Sedangkan sampel dalam penelitian ini sebanyak 30. Analisis yang digunakan dalam penelitian ini terdiri dari analisis univariat dan analisis bivariat menggunakan uji statistik T Test, Hasil analisa menggunakan uji statistik Paired T Test diperoleh nilai t hitung 22,027 > t tabel 2,045 yang menunjukkan terdapat pengaruh pemberian kue cucur tepung beras merah terhadap kadar glukosa darah puasa penderita Diabetes Mellitus tipe 2 di wilayah kerja Puskesmas Kulisusu Kabupaten Buton Utara. Pemberian cucur beras merah ini mampu menekan laju kadar glukosa darah sebesar $42,4 \%$ pada kelompok perlakuan yang dilihat pada persen selisih rata-rata kadar glukosa darah puasa dan glukosa darah 2 jam PP, Terdapat pengaruh pemberian cucur beras merah terhadap kadar glukosa darah penderita diabetes mellitus tipe 2 di wilayah kerja Puskesmas Kulisusu Kabupaten Buton Utara ketika dilihat hasil analisis statistik nilai t hitung 22,027 > t tabel 2,045, yang mana produk tersebut mampu menekan laju kadar glukosa darah 2 jam PP sebesar 42,4\% pada kelompok perlakuan. Produk cucur beras merah juga disukai oleh para panelis yang mana panelis tersebut merupakan penderita Diabetes Mellitus Tipe 2 di wilayah kerja Puskesmas Kulisusu Kabupaten Buton Utara setelah dilihat dari beberapa aspek penilaian seperti warna, aroma, rasa dan tekstur.
\end{abstract}

\section{PENDAHULUAN}

Diabetes Mellitus merupakan salah satu masalah kesehatan global di masyarakat. Pada tahun 2015 Indonesia menjadi peringkat ke tujuh dunia untuk prevalensi diabetes tertinggi bersa- ma dengan China, India, Amerika Serikat, Brazil dan Meksiko, Berdasarkan data riskesdas tahun 2018 secara Nasional, prevalensi DM yang terdiagnosa oleh dokter pada penduduk umur $>15$ tahun yaitu sebanyak 2\%. Selain itu 
prevalensi DM tahun 2018 berdasarkan pemeriksaan darah pada penduduk umur $>15$ tahun sebanyak 8,5\% dari 6,9\% di tahun 2013 (Riskesdas, 2018). Di tahun 2017 Penyakit diabetes melitus menjadi penyakit urutan ke-5 tertinggi di Provinsi Sulawesi Tenggara termasuk di Kabupaten Buton Utara dengan jumlah kasus 445 kasus rawat jalan diantaranya 342 kasus pada wanita dan 113 kasus pada pria (Anonim, 2017).

Pemicu munculnya penyakit degeneratif seperti diabetes mellitus terdiri dari bebrapa faktor yaitu keturunan, pola makan yang salah, life style, stress, faktor usia dan faktor lingkungan (Ruslan M, dkk 2015). Penderita diabetes mellitus disarankan untuk mengonsumsi makanan dengan indeks glikemik (IG) yang rendah agar tidak terjadi peningkakan kadar gula darah secara signifikan. Nilai Indeks Glikemik (IG) berkisar antara 1-100 yang kemudian dibagi lagi dalam tiga level, yaitu rendah $(<55)$, sedang (55-70), dan tinggi ( $>70$ ) (Anonim, 2009). Nilai indeks glikemik menunjukkan potensi gula darah dari karbohidrat yang mana makin tinggi bilangan glikemik maka semakin tinggi resiko naiknya kadar gula darah dan begitupula sebaliknya. (Astuti A, dkk 2017). Salah satu Indeks Glikemik dalam pangan yang termasuk dalam level rendah yaitu gula merah arendengan indeks glikemik 35 (Pudi 2012). Produksi gula aren di Sultra yang mulai meningkat pada tahun 2008 sebanyak 3.403 ton, tetapi sedikit menurun tahun 2010 menjadi 3.332 ton dan kemudian cenderung meningkat kembali pada tahun 2011 yaitu 3.370 ton (Ilma SR, 2016). Gula aren juga terkenal dapat menurunkan kadar glukosa darah. Seperti yang disebutkan oleh Sujarwo (2002) bahwa pemberian gula aren sebagai pengganti gula pasir pada penderita Diabetes Mellitus akan memberikan efek yang menguntungkan. Meski gula aren tergolong aman dikonsumsi oleh penderita Diabetes Mellitus, bukan berarti gula merah dapat dikonsumsi dengan bebas. Hal ini karena kandungan kalori dalam gula aren hampir setara dengan gula putih yaitu sekitar 4 gram karbohidrat dan 16 kalori per sendok teh. Oleh karena itu, Kementerian Kesehatan membatasi konsumsi gula maksimal 50 gram per hari atau setara dengan 4 sendok makan. Akan tetapi, indeks glikemik yang rendah pada gula aren akan diubah menjadi glukosa secara perlahan sehingga pankreas tidak perlu bekerja keras memproduksi insulin (Sujarwo, 2002).

Penyakit degeneratif seperti Diabetes Mellitus (DM) dapat dicegah dan diintervensi. Terdapat beberapa cara pencegahan penyakit Diabetes Melitus diantaranya adalah menjaga berat badan ideal, menjaga pola makan seimbang dengan target "tiga rendah dan satu tinggi" yaitu prinsip pola makan rendah lemak, rendah gula, rendah natrium, dan tinggi serat, serta tetap aktif berolahraga secara teratur dengan cara berolahraga setiap hari 30 menit atau lebih selama 5 hari dalam seminggu (Perkeni 2015).

Penatalaksanaan atau pengobatan penyakit Diabetes Mellitus meliputi terapi diet atau Terapi Nutrisi Medis (TNM), terapi farmakologi dan terapi edukasi. Terapi Nutrisi Medis (TNM) memiliki prinsip untuk mengatur makanan pada penderita DM hampir sama dengan anjuran makan untuk masyarakat umum, yaitu makanan yang seimbang dan sesuai dengan kebutuhan kalori dan zat gizi masing-masing individu. Penderita DM perlu diberikan penekanan mengenai pentingnya keteraturan jadwal makan, jenis dan jumlah kandungan kalori, terutama pada pasien yang menggunakan obat untuk meningkatkan sekresi insulin atau terapi insulin. Terapi farmakologi diberikan bersama dengan pengaturan makan dan latihan jasmani (gaya hidup sehat), yang terdiri dari obat oral (Obat Antihiperglikemia oral) dan bentuk suntik (Obat Antihiperglikemia suntik). Sedangkan terapi edukasi dengan tujuan promosi hidup sehat yang perlu selalu dilakukan sebagai bagian dari upaya pencegahan dan merupakan bagian yang sangat penting dari pengelolaan DM secara holistik. Materi edukasi terdiri dari materi edukasi tingkat awal dan materi edukasi tingkat lanjutan (Perkeni 2015).

Mengatur pola makan merupakan salah satu cara penatalaksanaan untuk penderita Diabetes Mellitus (Perkeni, 2015). Membatasi makanan yang tinggi nilai indeks glikemik merupakan cara yang perlu diperhatikan oleh penderita DM. Makanan dengan nilai IG tinggi memiliki resiko peningkatan kadar gula darah secara signifikan. Oleh karena itu, penignkatan konsumsi makanan dengan IG rendah lebih diutamakan. Salah satu pangan yang memiliki indeks glikemik dalam level rendah adalah beras merah. Beras merah mengandung Indeks glikemik yang lebih rendah dibandingkan dengan beras putih. Indeks glikemik (IG) pada beras putih 89 , beras merah yaitu 53,8, dan beras hitam 42,2. Jika dalam satu jenis pangan memiliki indeks glikemik yang tinggi mampu meningkatkan kadar glukosa darah dengan cepat begitu juga sebaliknya (Tamrin, 2014). Selain itu, beras merah juga memiliki kandungan serat kasar yang tinggi 
sehingga mampu meningkatkan rasa kenyang serta dapat menunda lapar. Serat kasar juga berguna bagi kesehatan pencernaan, dan membantu menurunkan konsentrasi LDL dalam darah serta mampu mengurangi resiko penyakit kronis seperti diabetes melitus (Hariati,N, dkk 2018). Beras merah memiliki beberapa manfaat bagi tubuh. Dalam 100g berat bahan, beras merah memiliki kandungan gizi energy 352 kkal, protein 7,3, lemak 0,9, dan karbohidrat 76,2 gr (TKPI 2017).

Beras merah merupakan salah satu pangan fungsional karena terkenal efektif dapat menurunkan kadar glukosa darah. Beras merah mempunyai daya tahan terhadap hama yang lebih tinggi sehingga memiliki prospek yang lebih baik. Di daerah Buton Utara, beras merah ditanam di ladang dengan hasil panen mencapai 421,0 ton di tahun 2017. Selain itu, ada beberapa wilayah yang menjadi tempat dipoduksinya beras merah seperti di wilayah Kecamatan Bonegunu dan Kambowa (Anonim, 2018), Beras merah tidak hanya dapat dikonsumsi sebagai nasi merah. Seiring dengan perkembangan teknologi, beras merah dapat diolah menjadi olahan sederhana salah satunya adalah tepung beras merah. Tepung merupakan bentuk alternatif produk setengah jadi yang berguna untuk menambah daya simpan, diperkaya zat gizi dan mudah diolah (Hariati,N, dkk 2018).

Pada penelitian ini, tepung beras merah akan menjadi bahan utama dalam pembuatan kue cucur. Seperti yang dilansir oleh kompasiana bahwa cucur merupakan makanan khas wilayah Asia Tenggara khususnya di Malaysia, Brunei Darussalam, Thailand, Srilanka, India, dan Indonesia. Cucur merupakan cemilan khas yang ada di Provinsi Sulawesi Tenggara termasuk di daerah Buton Utara disebabkan karena penyebarannya melalui imigran yang masuk ke tanah buton pada zaman dahulu. Cucur selalu hadir sebagai cemilan pada acara adat maupun agama seperti saat haroa atau biasa disebut dengan syukuran. Selain itu, cucur juga dapat dinikmati kapan saja dan dimana saja karena proses pembuatannya yang mudah serta tidak membutuhkan biaya yang banyak dan produksi cucur juga sudah menjadi salah satu mata pencaharian, sehingga cucur dapat ditemukan di pasar-pasar tradisional di Daerah Kabupaten Buton Utara. Cucur berbentuk bulat pipih, dikelilingi dengan pinggiran yang bergerigi dan renyah, ukurannya berbeda-beda, namun pada umumnya seukuran telapak tangan orang dewasa. Bahan utama pada kue cucur pada umumnya adalah tepung beras putih. Akan tetapi, kue cucur yang diinginkan oleh peneliti adalah cucur yang bisa dikonsumsi oleh penderita Diabetes, oleh sebab itu subtitusi tepung beras merah sebagai bahan utama menjadi fokus peneliti karena beras merah sudah terbukti dapat menurunkan kadar glukosa darah (Herlina D,N, dkk 2017).

Berdasarkan gambaran di atas maka peneliti tertarik untuk melakukan penelitian tentang pengaruh pemberian cucur tepung beras merah (oriza nivara l.) terhadap penurunan kadar glukosa darah pada penderita diabetes melitus tipe 2 di wilayah kerja Puskesmas Kulisusu Kabupaten Buton Utara.

\section{METODE PENELITIAN}

Jenis penelitian ini adalah penelitian eksperimental dengan desain penelitian pre and post control desain. Pada penelitian ini akan melihat efektifitas pemberian kue cucur tepung beras merah dalam menurunkan kadar glukosa darah penderita Diabetes Melitus di wilayah kerja puskesmas Kulisusu kabupaten buton utara. Penelitian ini dilaksanakan pada bulan Maret hingga April tahun 2020 di Wilayah Kerja Puskesmas Kulisusu di Kabupaten Buton Utara, Populasi yang dituju adalah penderita Diabetes Melitus Tipe IIdi wilayah kerja Puskesmas Kulisusu Kabupaten Buton Utara sebanyak 113 kasus rawat jalan yang tersebar di beberapa kelurahan. Sedangkan sampel ntuk sampel studi kasus dan uji organoleptik adalah penderita Diabetes Melitus Tipe II di wilayah kerja Puskesmas Kulisusu Kabupaten Buton Utara khususnya di Kelurahan Lipu dan di Kelurahan Wandaka sebanyak 30 , Jenis pengumpulan data yang digunakan adalah non participan observation pada subjek yang menjadi sampel peneliti:

1. Data Primer

Data primer dalam penelitian ini adalah data identitas responden, yang dikumpulkan dari wawancara dengan alat bantu kuesioner. Kemudian, data primer kedua adalah data kadar glukosa darah. Untuk data ini dikumpulkan dengan cara biokimia dengan alat bantu glukometer (Nesco) pada pembuluh darah tepi, meliputi gula darah sewaktu (GDS), gula darah puasa (GDP), dan gula darah 2 jam PP (GD 2 jam PP), Selanjutnya, data uji daya terima, yang dikumpulkan dengan menggunakan angket beserta pertanyaan dengan alat bantu kuesioner. 
2. Data Sekunder

Data sekunder meliputi data geografi, demografi dan topografi diperoleh dari profil Puskesmas Kulisusu dan data Kecamatan Kulisusu dalam angka, pengolahan dan penyajian data dalam penelitian ini dilakukan dengan:

a. Kadar Glukosa Darah

Data kadar glukosa darah diolah dari hasil pengukuran gula darah sewaktu, gula darah puasa, dan gula darah 2 jam PP. Setelah itu disajikan dalam bentuk tabel.

b. Daya terima produk

Data daya terima diolah berdasarkan hasil angket kemudian dikelompok kan berdasarkan skala liker mulai dari sangat tidak suka, tidak suka, suka, dan sangat suka. Kemudian disajikan dalam bentuk table, Analisis data dilakukan dengan beberapa tahapan, diantaranya:

a. Unuivariate

Analisis Univariat yaitu dengan menganalisis variable-variabel yang ada secara deskriptif dengan menghitung distribusi, frekuensidan persentase dari seluruh data yang diperoleh.

b. Bivariate

Analisa Bivariat yaitu digunakan untuk membuktikan hipotesis penelitian antara variableindependen dan dependen dengan menggunakan uji statistik yaitu uji $\mathrm{T}$ ( $\mathrm{T}$ test).

\section{HASIL DAN PEMBAHASAN}

1. Pengaruh Pemberian Kue Cucur Tepung Beras Merah Dalam Menurunkan Kadar Gula Darah Penderita Diabetes Melitus Tipe 2 Di Wilayah Puskesmas Kulisusu Kabupaten Buton Utara

Berdasarkan hasil analisa menggunakan uji statistik Paired $\mathrm{T}$ Test dengan nilai $\mathrm{t}$ hitung 22,027 > t tabel 2,045 menunjukkan terdapat pengaruh pemberian kue cucur tepung beras merah terhadap kadar glukosa darah puasa penderita Diabetes Mellitus tipe 2 di wilayah kerja Puskesmas Kulisusu Kabupaten Buton Utara. Pemberian cucur beras merah ini mampu menekan laju kadar glukosa darah sebesar $42,4 \%$ pada kelompok perlakuan yang dilihat pada persen selisih rata-rata kadar glukosa darah puasa dan glukosa darah 2 jam PP.

Hasil penelitian ini sejalan dengan hasil penelitian yang dilakukan oleh candra, dkk., (2018) menyatakan nasi beras merah dapat menurunkan kadar glukosa darah secara signifikan. Selanjutnya, menurut pauzi, dkk., (2017) menyatakan pemberian tepung beras merah selama 14 hari berpengaruh secara signifikan terhadap kadar glukosa darah hewan coba tikus putih galur wistar. Hasil penelitian lain darmawati, dkk., (2017) menyatakan bahwa beras merah 6,75 gram/ hari merupakan dosisi yang tepat untuk memperoleh kadar gula darah yang optimal.

Penurunan kadar glukosa darah bisa disebabkan kandungan antosianin yang terkandung dalam beras merah. Antosianin termasuk pigmen kelompok flavonoid yang menghasilkan warna jingga, merah dan biru bersifat larut dalam air dan mudah mengalami degradasi. Degradasi antosianin dapat disebabkan $\mathrm{pH}$, cahaya, suhu, dan penambahan gula. Zat antosianin yang cukup tinggi sebagai antioksidan yang dapat mengurangi resiko diabetes melitus. Diketahui bahwa diet antioksidan, termasuk antosianin, melindungi sel $\beta$-pankreas dari stres oksidatif glucose induced (Anjani dkk., 2018).

Komponen utama beras merah juga yaitu oryzanol mampu meningkatkan intoleransi glukosa, mencegah obesitas, dan DM tipe 2. Kandungan proteinnya juga lebih tinggi, dengan adanya kandungan protein yang tinggi ini diharapkan mampu memperbaiki kondisi glikemik pada pasien Diabetes Mellitus, dengan cara memperbaiki struktur sel beta pankreas yang sangat berpengaruh pada pengaturan hormon insulin. Pemberian tepung beras merah dapat melindungi sel dari pengaruh buruk radikal bebas. Radikal bebas adalah senyawa atau atom yang memiliki elektron tidak berpasangan pada orbital luarnya sehingga bersifat sangat reaktif terhadap sel atau komponen sel seperti lipid, protein dan DNA, serta dapat menyebabkan mutasi dan bersifat karsinogenik. Dalam keadaan normal, radikal bebas yang diproduksi didalam tubuh akan dinetralisir oleh antioksidan endogen, jika kadar radikal bebas terlalu tinggi terjadi keadaan yang tidak seimbang antara radikal bebas dengan antioksidan disebut stres oksidatif. Salah satu indikator untuk menentukan stres oksidatif pada manusia adalah kadar MDA (malondialdehyde) yang merupakan hasil dari peroksidasi lipid didalam tubuh akibat radikal bebas. Zat antosianin yang terkandung dalam beras merah dapat dimanfaatkan karena kandungannya dapat mengontrol kadar glukosa darah sehingga dapat mencegah terjadinya resisten 
insulin pada pendertita DM (Anjani dkk, 2018)

\section{Daya Terima Cucur Tepung Beras Merah}

Beras merah atau brown rice adalah beras yang tidak digiling atau setengah digiling, jadi bisa dikatakan whole grain atau berbutir utuh. Beras merah mempunyai rasa sedikit seperti kacang dan lebih kenyal daripada beras putih. beras merah umumnya diolah dengan ditumbuk atau dipecah kulitnya. Hal ini membuat kulit arinya yang berwarna merah masih utuh. Pada kulit arinya inilah terdapat kandungan protein, vitamin, mineral dan serat yang sangat penting bagi tubuh (Kuszairi, 2008).

Beras merah merupakan bahan makanan pokok yang mempunyai kandungan protein lebih tinggi dibandingkan beras putih, disamping faktor penanganan pasca panen beras merah yang biasanya masih mengandung kulit ari (pecah kulit) yang sangat menguntungkan yang dapat menghambat risiko diabetes. Proses pengecambahan sereal seperti beras, dapat meningkatkan nilai gizi seperti serat dan protein (Nurrahman dan Nurhidajah, 2014), Rata-rata persentase terbesar penerimaan panelis daya terima cucur tepung beras merah di kategori cukup suka sebesar 63,4\%.

\section{SIMPULAN DAN SARAN}

\section{A. Simpulan}

Beberapa simpulan yang dapat disampaikan dalam penelitian antara lain:

1. Diperoleh rata-rata hasil pengukuran kadar glukosa darah puasa 119,70 mg/dl, rata-rata hasil pengukuran kadar glukosa darah 2 jam PP 169,80 mg/dl dan rata-rata hasil pengukuran kadar glukosa darah sewaktu $224,83 \mathrm{mg} / \mathrm{dl}$.

2. Terdapat pengaruh pemberian cucur beras merah terhadap kadar glukosa darah penderita diabetes mellitus tipe 2 di wilayah kerja Puskesmas Kulisusu Kabupaten Buton Utara ketika dilihat hasil analisis statistik nilai $\mathrm{t}$ hitung 22,027 $>\mathrm{t}$ tabel 2,045, yang mana produk tersebut mampu menekan laju kadar glukosa darah 2 jam PP sebesar $42,4 \%$ pada kelompok perlakuan.

3. Produk cucur beras merah disukai oleh para panelis yang mana panelis tersebut merupakan penderita Diabetes Mellitus Tipe 2 di wilayah kerja Puskesmas Kulisusu Kabupaten Buton Utara setelah dilihat dari beberapa aspek penilaian seperti warna, aroma, rasa dan tekstur.

\section{B. Saran}

Diharapkan agar penderita Diabetes Mellitus Tipe 2 lebih memperhatikan pola makan dengan selalu mengkonsumsi makanan yang rendah kadar indeks glikemik serta kaya akan serat agar dapat membantu memperbaiki keadaan kadar glukosa dalam darah menjadi lebih baik.

\section{DAFTAR RUJUKAN}

American Diabetes Association. 2012. Standards of Medical Care in Diabetes. Clinical Practice Recommendation.

Anonim. 2009. Beras untuk Penderita Diabetes. Warta Penelitian dan Pengembangan Pertanian. Vol 31. No.2.

Anonim. 2018. Laporan Nasional Riset Kesehatan Dasar. Kementrian Kesehatan RI. Badan Litbang Kesehatan.

Anonim. 2017. Profil Kesehatan Provinsi Sulawesi Tenggara tahun 2017. Dinas Kesehatan Provinsi Sulawesi Tenggara.

Anonim. 2014. Situasi dan Analisis Diabetes. Kementrian Kesehatan RI.

Anonim. 2017. Tabel Komposisi Pangan Indonesia. Kementrian Kesehatan RI.

Cindy Sanggar Velanie1, Maruni Wiwin Diarti, Iswari Pauzi., 2017. Pemberian Tepung Beras Merah (Oryza Nivara) Terhadap Penurunan Kadar Glukosa Darah Pada Hewan CobaTikus Putih (Rattus Norvegicus) Galur Wistar. Jurnal Analis Medika Bio Sains Vol.4, No.2, September 2017, Hal. 81-86

Ebigail Daeli, Martha Ardiaria, Aryu Candra., 2018. Pengaruh Pemberian Nasi Beras Merah (Oryza nivara) dan Nasi Beras Hitam (Oryza sativa L.indica) terhadap Perubahan Kadar Gula Darah dan Trigliserida Tikus Wistar (Rattus norvegicus) Diabetes Melitus Tipe 2. JNH(Journal of Nutrition and Health) Vol.6 No.2

Hariati N, dkk. 2018. Pengaruh Penambahan Tepung Beras Merah (Oriza Nivara L.) Terhadap Uji Organoleptik Dan Proksimat 
Bolu Kukus. Jurnal Sains dan Teknologi Pangan. Vol.3 No.1 Hal 1006-1017.

Herlina D,N, dkk. 2017. Pengaruh Pemberian Beras Merah Terhadap Kadar Gula Darah Tikus Wistar. Media Medika Muda. Vol. 2 No.2 Hal 83-88.

Kuszairi, 2008. Efektifitas Pemberian Diet Beras Merah Dalam Menurunkan Kadar Gula Darah Pada Penderita Diabetes Mellitus Di Puskesmas Pademawu Pamekasan. Akper Pemkab Pamekasan Madura

Melisa Ruslan, dkk.2015. Daya Terima Dan Indeks Glikemik Makanan Brownies Yang Diperkaya Tepung Beras Merah Dan Kurma. Media Gizi Indonesia. Vol.10 No.2 Hal 166-172.

Nurhidajah dan Nurrahman, 2014. Potensi Kecambah Beras Merah Pada Penurunan Kadar Glukosa Darah Dan Efektifitasnya Terhadap Perubahan Berat Badan Tikus Yang Diinduksi Stz-Na. Program Studi Teknologi Pangan Universitas Muhammadiyah Semarang
Paudi, F. 2012. Kandungan Nutrisi Gula Merah Kelapa. The Philippine Food and Nutrition Research Institute.

Soelistijo S,A, dkk. 2015. Konsensus Pengelolaan dan Pencegahan Diabetes Melitus Tipe 2 di Indonesia. PB Perkeni.

Sugiyono. 2017. Metode Penelitian Kuantitatif, Kualitatif dan R\&D. Bandung : Penerbit Alfabeta.

World Health Organization (WHO). 2015. Diabetes Fakta dan Angka.

Yuriska, F., Anindhita. 2009. Efek Aloksan Terhadap Kadar Glukosa Darah Tikus wistar. Jurnal Fakultas Kedokteran Universitas Diponegoro Semarang. 